\title{
Трансанальні ендоскопічні операції при пухлинах прямої кишки
}

\author{
В. В. Грубнік, Р. П. Никитенко, С. П. Дягтяренко, В. В. Грубнік
}

Одеський національний медичний університет

\section{Transanal endoscopic operations in rectal tumors}

\author{
V. V. Grubnik, R. P. Nikitenko, S. P. Degtyarenko, V. V. Grubnik
}

Odessa National Medical University

\begin{abstract}
Реферат
Мета. Покращити діагностику та результати лікування хворих з пухлинами прямої кишки шляхом застосування трансанальної ендоскопічної мікрохірургії і вивчення «сторожових» лімфатичних вузлів.

Матеріали і методи. За період 32009 по 2017 р. у клініці трансанальні ендоскопічні операції виконані 115 хворим у віці від 29 до 82 років. У 92 пацієнтів була тубуловорсинчата аденома прямої кишки, із них у 26 гістологічним дослідженням видалених пухлин виявлено малігнізацію (TisNOMO). У 23 пацієнтів до операції виявлено ранній рак прямої кишки T1-2NOMO.

Результати. У строки спостереження від 12 до 60 міс рецидив виявили у 2 (2,2\%) хворих з аденомою і у 3 (13\%) 3 раком прямої кишки. Рецидив раку виник у хворих, які відмовилися від хіміотерапії та променевої терапії.

Висновки. Ідентифікація і прицільне дослідження «сторожових» лімфатичних вузлів при раку прямої кишки уможливлює вірогідну (чутливість=0,89, специфічність=0,99) оцінку стадії захворювання і застосування адекватної схеми комбінованого і комплексного лікування пацієнтів.

Ключові слова: рак прямої кишки; «сторожові» лімфатичні вузли; ендоскопічна резекція.

Abstract

Objective. To improve diagnosis and results of treatment in patients, suffering rectal tumors, using transanal endoscopic microsurgery and studying of sentinel lymphatic nodes.

Materials and methods. In 2009 - 2017 yrs in the Clinic transanal endoscopic operations were performed in 115 patients, ageing $29-82$ yrs old. Tubulo-villous rectal adenoma was in 92 patients, of them in 26 histological investigation of the tumors excised have revealed malignization (TisNOMO). In 23 patients early cancer recti T1-2NOMO was revealed preoperatively. Results. During follow-up 12 - 60 mo the recurrence was revealed in 2 (2.2\%) patients, suffering adenoma, and in 3 (13\%) suffering cancer recti. Recurrence of cancer have occurred in patients, who rejected conduction of chemotherapy and radiation therapy.

Conclusion. Identification and precise investigation of sentinel lymphatic nodes in patients, suffering cancer recti makes possible a trustworthy (sensitivity $=0.89$, specificity $=0.99$ ) estimation of the disease and application of adequate scheme of combined and complex treatment of the patient.

Keywords: cancer recti; sentinel lymphatic nodes; endoscopic resection.
\end{abstract}

Лімфогенне метастазування є однією із найважливіших причин виникнення місцевого рецидиву раку прямої кишки (РПК) та несприятливим фактором прогнозу $[1,2]$. За даними окремих авторів, у хворих з РПК та ураженням регіонарних лімфатичних вузлів (ЛВ) п'ятирічна виживаність не перевищувала 45\%, тоді як у хворих 3 РПК без ураження ЛВ п'ятирічна виживаність збільшувалась до 70\% [3].

Досі немає методики, що однозначно дає змогу виявити ураження регіонарних ЛВ у хворих з РПК [1]. Основним критерієм, за яким можливо опосередковано судити про метастатичне ураження ЛВ, є його розмір [5, 6]. Водночас розміри ЛВ не завжди свідчать про їх залученість у пухлинний процес або інтактність [4]. Є повідомлення про те, що ЛВ менше 5 мм у діаметрі були метастатично ураженими у 15\% хворих [5].

Тривалий час місцеве поширення РПК оцінювали за даними ендоректального ультразвукового дослідження
(ЕРУЗД) прямої кишки [3, 6]. За точністю оцінки локальної інвазії пухлини це дослідження можна порівняти 3 магнітно-резонансною томографією (МРТ) [6]. Але МРТ і ЕРУЗД як методи доопераційного стадіювання пухлинного процесу прямої кишки не мають належної чутливості та специфічності щодо оцінки регіонарного метастазування в цілому і ураження латеральної групи ЛВ зокрема $[6,7]$, що свідчить про необхідність пошуку нових методів діагностики, виявлення факторів ризику і несприятливого прогнозу щодо латерального метастазування у хворих з РПК, а також більш диференційованого підходу до вибору лікувальної тактики.

Одним із важливих факторів метастазування пухлини $€$ наявність «сторожового» ЛВ. Виявлення «Сторожового» ЛВ має значення для діагностики і визначення інтенсивності злоякісного розростання, оскільки з метастазування в регіонарні лімфатичні вузли починається поширення більшості злоякісних новоутворень [7]. 
Мета дослідження: покращити діагностику та результати лікування хворих з пухлинами прямої кишки шляхом застосування методики трансанальної ендоскопічної мікрохірургії (ТЕМ) і вивчення «Сторожових» ЛВ.

\section{Матеріали і методи дослідження}

Методика ТЕМ впроваджена в нашій клініці в 2003 р. Спочатку операції виконували за класичною методикою з використанням операційного ректоскопа, проте з 2007 p. більшість таких операцій виконуємо через спеціальний порт фірми «Covidien». Для виконання операції використовуємо відеоендоскопічну стійку фірми «Karl Storz» і спеціальні ендоскопічні інструменти прямі та вигнуті: затискачі, дисектори, ножиці, голкотримач, кліпатор.

За період з 2009 по 2017 р. у клініці із застосуванням методики ТЕМ оперовані 115 хворих у віці від 29 до 82 років. У 92 пацієнтів була тубуловорсинчата аденома прямої кишки, із них у 26 гістологічним дослідженням видалених пухлин виявлено малігнізацію (TisNOM0). У 23 пацієнтів до операції виявлено ранній РПК Т1-2 N0M0. Вік цих пацієнтів коливався від 59 до 82 років. У 12 пацієнтів була II стадія раку, що потребувало проведення неоад'ювантної хіміотерапії та променевої терапії. У такий спосіб ми домоглися зменшення розмірів пухлини і ііі інвазіі в стінку прямої кишки, а також зниження ризику метастазування в регіонарні ЛВ.

Хворих інформували про можливі ускладнення і необхідність виконання в подальшому розширених радикальних операцій. Від усіх пацієнтів отримано письмову інформовану згоду на виконання операції саме за методикою ТЕМ. Перед операцією хворі були ретельно клінічно обстежені. Їм виконували ректоскопію, фіброколоноскопію, іригоскопію, трансректальне ультразвукове дослідження (УЗД), МРТ органів малого таза з визначенням збілышених ЛВ, за показаннями мультиспіральну комп'ютерну томографію (МКТ) органів черевної порожнини.

Проведення передопераційної підготовки відповідало стандарту. Для профілактики тромбоемболічних ускладнень всім хворим призначали носіння компресійного трикотажу або бинтування нижніх кінцівок еластичними бинтами, низькомолекулярні гепарини, ранню активізацію після операції.

Всі операції виконували під ендотрахеальним наркозом у положенні пацієнтів на спині. У пряму кишку вводили спеціальний порт з трьома троакарами: одним 10міліметровим - для ендоскопа і двома 5-міліметровими - для інструментів. У окремих хворих використовували 5-міліметровий ендоскоп. Після інсуфляції вуглекислого газу за допомогою електрокоагулятора маркували зони резекції, відступивши не менше 10 мм від краю пухлини. Резекцію виконували пошарово з допомогою електрогачка або коагуляційних затискачів апарата «LigaSure».

Після резекції пухлини пряму кишку промивали розчином бетадину і зашивали рану безперервними або вузловими швами ниткою «Вікрил» $3 / 0$ або «V-Lock» фipми Covidien.

\section{Результати}

Тяжких інтраопераційних ускладнень не було, жоден пацієнт не помер. У післяопераційному періоді у 2 хворих, оперованих з приводу РПК, виникла гостра кровотеча, їм виконали повторну операцію за методикою ТЕМ, під час якої судини ретельно коагулювали і прошили. Хворі одужали.

Нижній край пухлини знаходився на висоті в середньому $(8,5 \pm 1,2)$ см від відхідника (від 5 до 18 см), розмір пухлини становив у середньому $(4,2 \pm 0,7)$ см (від 1,5 до 11 см). Під час гістологічного дослідження видалених препаратів у всіх спостереженнях визначено, що пухлина видалена в межах здорових тканин. Інтраопераційне проникнення в черевну порожнину було у 2 (1,7\%) хворих, коли пухлина розташовувалась на висоті 13 і 18 см від відхідника. В обох спостереженнях дефект кишки закрили лапароскопічно з боку черевної порожнини без накладення розвантажувальної колостоми. Герметичність швів перевіряли під час операції за появою бульбашок повітря, коли нагнітали в пряму кишку газ. Обидва хворих видужали без ускладнень.

Ранові дефекти в прямій кишці зажили задовільно у всіх пацієнтів, що підтверджено наступними контрольними оглядами та ендоскопічними дослідженнями у віддаленому періоді. Гнійно-септичних, тромбоемболічних та урологічних ускладнень у оперованих хворих не було.

Спостерігали за оперованими хворими у строки від 12 до 60 міс. Рецидив виявили у 2 (2,9\%) хворих з аденомою прямої кишки і у 3 (13\%) - з РПК. Рецидив раку виник у тих хворих, які відмовилися від хіміотерапії та променевої терапії.

Хворих з рецидивами оперували повторно. У хворих 3 рецидивом аденоми повторно виконали висічення пухлини за методикою ТЕМ, з рецидивом раку - лапаротомію і низьку резекцію прямої кишки.

3 огляду на можливість рецидиву і метастазування у хворих після виконання локального висічення пухлин за методикою ТЕМ, ми вдосконалили дану методику.

Виконуючи операцію за методикою ТЕМ, у підслизовий шар пухлини вводимо 1 - 2 мм барвника індоціаніну зеленого. Через 15 хв після цього виконуємо лапароскопію і бачимо забарвлені регіонарні ЛВ. Для більш чіткої візуалізації «сторожових» лімфатичних судин і регіонарних ЛВ використовуємо режим ультрафіолетового підсвічування, який має сучасна апаратура фірми «Storz». Видаляємо «сторожові» ЛВ і проводимо їх термінове гістологічне дослідження. Якщо в ЛВ мікрометастазів раку немає, виконуємо локальне видалення пухлини за методикою ТЕМ. За наявності метастатичного ураження «сторожових» ЛВ виконуємо лапароскопічну або відкриту резекцію прямої кишки з обов'язковим видаленням мезоректуму і періампулярної клітковини - тотальну мезоректектомію (TME).

За останні два роки подібні операції виконали у 7 пацієнтів з II стадією РПК (T2NOM0). У 5 пацієнтів у «Сторожових» ЛВ не виявили метастазів раку. Їм виконали ради- 
кальне видалення пухлини за методикою ТЕМ. У 2 пацієнтів виявили мікрометастази раку в регіонарних ЛВ. Їм виконали низьку резекцію прямої кишки з радикальним видаленням мезоректуму: у одного пацієнта застосовували лапароскопічну методику, у одного - лапаротомію. Накладено низькі ректальні анастомози циркулярними апаратами з додатковою розвантажувальною ілеостомою. Обидва пацієнти одужали. Ілеостому закрили через 4 - 6 міс. У всіх 7 пацієнтів упродовж спостереження до 2 років локального рецидиву пухлини та віддалених метастазів не виявлено.

Нами встановлено, що ідентифікація і прицільне дослідження «сторожових» ЛВ у хворих з РПК дає змогу вірогідно (чутливість $=0,89$, специфічність $=0,99$ ) оцінити стадію захворювання і провести пацієнту адекватне комбіноване і комплексне лікування.

\section{Обговорення}

Роль ТЕМ у лікуванні РПК є дискутабельною, оскільки локальне видалення пухлини не супроводжується лімфаденектомією [8]. В останні роки з'явилися повідомлення, що у окремих хворих з пухлиною стадії Т2 на тлі неоад'ювантної радіохіміотерапії можливе виконання операції за методикою ТЕМ [4]. Використання ендоскопічного УЗД, а також МРТ вважають ключовим у діагностиці метастазування в ЛВ. Опубліковані результати лікування 7378 хворих з РПК, яким було виконано локальне висічення пухлини прямої кишки, і 36116 пацієнтів, яким виконали трансабдомінальну резекцію прямої кишки [5]. Віддалені результати (10 років) у хворих із стадією Тis-1 були однаковими, однак у хворих із стадією Т2 результати операції за методикою ТЕМ були значно гірше. Якщо хворі з II стадією РПК отримували перед операцією неоад'ювантну хіміотерапію та променеву терапію, результати ТЕМ і абдомінальної резекції прямої кишки не відрізнялися [9].

Частота серйозних ускладнень і летальність набагато нижче, якщо виконати локальне висічення пухлини за методикою ТЕМ, ніж у разі виконання лапароскопічної резекції прямої кишки з ТМЕ - 8,2 та 47,2\% (p=0,01) і 0 та $3,68 \%(p=0,01)$ відповідно, крім того значно скорочується тривалість перебування хворих у лікарні [5, 9].

Тому дуже перспективно розширити показання до виконання операцій за методикою ТЕМ у хворих з I і II стадіями РПК. 3 метою уточнення показань до можливого застосування таких операцій ряд авторів пропонує дослідити «сторожові» ЛВ у хворих з раннім РПК, щоб виявити метастазування [7]. Для цього використовують радіоактивний технецій-99, а також барвник індоціанін зелений. Ми, застосовуючи барвник індоціанін зелений, чітко виявляли «сторожові» ЛВ для їх інтраопераційної ідентифікації і видалення. Відсутність у регіонарних ЛВ мікрометастазів раку є обгрунтуванням для локального видалення пухлини за методикою ТЕМ. У жодного хворого ми не виявили рецидиву або метастазування раку в строки спостереження до двох років. Звичайно, слід врахувати, що отримані нами дані є попередніми і потребують більш ретельного підтвердження. Доцільні багатоцентрові дослідження для підтвердження гіпотези про роль «сторожових» ЛВ і можливість локального видалення пухлини у хворих з раннім РПК.

\section{Висновки}

1. Одним з найбільш важливих прогностичних факторів розвитку місцевого рецидиву РПК є метастазування в регіонарні ЛВ.

2. Ідентифікація і прицільне дослідження «сторожових» ЛВ у хворих з РПК уможливлюють вірогідно (чутливість $=0,89$, специфічність = 0,99) оцінити стадію захворювання і застосувати у них адекватну схему комбінованого і комплексного лікування.

3. Методика дослідження «сторожових» ЛВ у хворих 3 РПК має високу діагностичну цінність щодо виявлення лімфогенних метастазів і дає змогу розширити оперативне втручання до радикального об'єму.

\section{Підтвердження \\ Фінансування. Власні кошти. \\ Інформація про внесок кожного учасника}

Внесок кожного автора в цю роботу однаковий. Всі автори прочитали і схвалили остаточний варіант рукопису.

\section{Конфлікт інтересів}

Автори, які взяли участь в цьому дослідженні, декларують відсутність конфлікту інтересів щодо цього рукопису.

Згода на публікацію

Всі автори дали згоду на публікацію цього рукопису.

\section{References}

1. Ol'shanskiy MS, Korotkikh NN, Ponomareva YeN, Kazarezov OV. Endovaskulyarnoye lecheniye mestno-rasprostranennogo raka pryamoy kishki s uchetom osobennostey yeye krovosnabzheniya (obzor literatury i sobstvennyye nablyudeniya). Onkologicheskaya koloproktologiya. 2013;1(8):29-34. [In Russian].

2. Konishi T, Kuroyanagi H, Oya M, Ueno M, Fujimoto Y, Akiyoshi T, et al. Multimedia article. Lateral lymph nodedissection with preoperative chemoradiation for locally advanced lower rectal cancerthrough a laparoscopic approach. Surg Endosc. 2011 Jul;25(7):2358-9. doi: 10.1007/ s00464-010-1531-y.

3. Quadros CA, Falcao MF, Carvalho ME, Ladeia PA, Lopes A. Metastases to retroperitoneal or lateralpelvic lymph nodes indicated unfavorable survival and high pelvic recurrence rates in acohort of 102 patients with low rectal adenocarcinoma. J Surg Oncol. 2012 Nov;106(6):6538. doi: $10.1002 /$ jso. 23144

4. Lezoche E, Baldarelli M, Lezoche G, Paganini AM, Gesuita R, Guerrieri M. Randomized clinical trial of endoluminal locoregional resection versus laparoscopic total mesorectal excision for T2 rectal cancer after neoadjuvant therapy. Br J Surg. 2012 Sep;99(9):1211-8. doi: $10.1002 /$ bjs. 8821 .

5. Morino M, Risio M, Bach S, Beets-Tan R, Bujko K, Panis Y, et al. Early rectal cancer: the European Association for Endoscopic Surgery (EAES) clinical consensus conference. Surg Endosc. 2015 Apr;29(4):755-73. doi: 10.1007/s00464-015-4067-3.

6. Bilhim T, Pereira JA, Tinto HR, Fernandes L, Duarte M, O'Neill JE, et al. Middle rectal artery: myth or reality? Retrospective study with CT angiography and digital subtraction angiography. Surg Radiol Anat. 2013 Aug;35(6):517-22. doi: 10.1007/s00276-012-1068-y. 
7. Yermakov AV, Saribekyan EK, Ablitsova NV, Usov FN. Storozhevyye limfatichesike uzly pri zlokachestvennykh novoobrazovaniyakh. Zlokachestvennyye opukholi. 2017;1(22):70-7. doi: 10.18027/2224-50572017-1-70-77 [In Russian].

8. Allaix ME, Arezzo A, Arolfo S, Caldart M, Rebecchi F, Morino M. Transanal endoscopic microsurgery for rectal neoplasms. How I do it. J Gas- trointest Surg. 2013; Mar;17(3):586-92. doi: 10.1007/s11605-0122060-X.

9. Wu Y, Wu YY, Li S, Zhu BS, Zhao K, Yang XD, et al. TEM and conventional rectal surgery for T1 rectal cancer: a meta-analysis. Hepatogastroenterology. 2011 Mar-Apr;58(106):364-8. PMID: 21661397. 